\title{
Anti-terrorist activities of the future officers: essential and structural specifications
}

\author{
A.A. Laptev ${ }^{1}$, V.V. Kosukhin ${ }^{2 *}$, and I.G. Lomakina ${ }^{3}$ \\ ${ }^{1}$ Novosibirsk Military Institute named after General of the Army I.K. Yakovlev of the National Guard \\ of the Russian Federation, Novosibirsk, Russia \\ ${ }^{2}$ Novosibirsk Military Institute named after General of the Army I.K. Yakovlev of the National Guard \\ of the Russian Federation, Novosibirsk, Russia \\ ${ }^{3}$ Novosibirsk Military Institute named after General of the Army I.K. Yakovlev of the National Guard \\ of the Russian Federation, Novosibirsk, Russia
}

\begin{abstract}
The issues of the fight against terrorism and the training of law enforcement personnel to participate in this fight are currently particularly relevant. This is due to the fact that on the one hand, terrorism evolves and builds its activities taking into account the anti-terrorist policy, on the other hand, international terrorism has long ceased to be a «thing in itself», it is actively but covertly used by many countries and political forces to gain benefits and achieve their goals. The article examines the characteristics of anti-terrorist activities and the conditions in which their skills are formed. The research methodology is based on the system and activity approaches and functional analysis. The main scientific results of the study were that the characteristics of the anti-terrorist activities of future officers were revealed and the structure of readiness for this activity was clarified, the pedagogical conditions for the formation of the readiness of future officers for anti-terrorist activities were given, the optimization of the educational process was modeled in order to form the readiness of future officers for anti-terrorist activities.
\end{abstract}

\section{Problem statement}

At present, terrorism remains a convenient and quite effective means of intimidating the population, government bodies, officials and even members of the security forces. Largescale terrorist attacks today can paralyze the lives of entire regions and countries, and can also be aimed at changing the constitutional system.

The evolution of terrorism consists in the use of various social strata to facilitate and participate in this illegal activity, the increasing sophistication and use of advanced information and combat technologies, as well as a significant expansion of possible targets of attacks.

In Russia, the situation with terrorist acts remains tense. International terrorism actively cultivates religious and cultural contradictions, territorial and national conflicts, social insecurity of certain segments of the population and their low educational level.

${ }^{*}$ Corresponding author: prof-ped.gpa@mail.ru 
Actively using the fact that hundreds of different nationalities live on the territory of our country with their own cultural-value and value-religious ideas. International terrorism was one of the reasons for the bloody wars in the North Caucasus region in the late XX-early XXI century.

It is logical that our society and state cannot ignore the challenges that have emerged, which are dictated by the active activities of terrorist organizations on the territory of our country and are aimed at destabilizing public and political life, violating the rights of Russian citizens, and violating its territorial and moral integrity. At the same time, in achieving these goals, terrorist organizations are actively, but secretly, connived at by countries that only yesterday declared themselves allies and partners of our country in the international arena.

One of these responses was the formation of law enforcement agencies in the structure of the federal executive authorities, whose main purpose is to fight terrorism, prevent and prevent terrorist acts, ensure the security of individuals, society and the state, and participate in the fight against international terrorism outside the territory of the Russian Federation.

Since the officer cadres who will later manage the units, participating in anti-terrorist activities, are trained within the walls of military institutions, they need to form and develop their readiness to carry out such activities during the training period.

\subsection{The objective of the work}

The main purpose of the work is to reveal the essential and structural characteristics of the anti-terrorist activities of future officials, for which they are preparing in educational institutions of higher education. Methodological issues of the system approach, which has the function of a methodological reference point for this study, are considered in scientific works.

So Ludwig von Bertalanfi in his famous work believed that the general theory of systems in the narrow sense, trying to derive from the general definition of the concept of «system» as a complex of interacting components, a number of concepts characteristic of organized wholes, such as interaction, sum, mechanization, centralization, competition, finality, etc., and applying them to specific phenomena [1].

I.V. Blauberg and V. N. Sadovsky cover the philosophical aspects of systems research and the theoretical and cognitive problems of the system approach to concrete scientific knowledge. Outlining the problems of logical and methodological analysis as a special sphere of the system approach, the authors characterize the conceptual apparatus of modern system research, the successes and gaps in its development [2].

Stepin V.S. believed that the choice of a scientific discipline as a system of developing theories, considered in their interaction with each other and experience, as well as included in interdisciplinary interactions, as a unit of methodological analysis is adequate to the system representation [3].

The theoretical and methodological foundations of the study of the formation and development of readiness for anti-terrorist activities, and in particular the conceptual ideas about the essence and features of professional activity are reflected in the works of K.A. Abulkhanova-Slavskaya [4].

G.G. Dmitriev believes that the main tasks of the psychological training of military personnel are: the formation of mental strength to overcome difficulties and a willingness to resist the stronger the enemy [5].

A.G. Karani offers a model approach to the psychological training of military personnel, where its goals, objectives, forms and methods are derived from psychological models of a 
particular battle, from the content, specificity and hierarchy of factors that will determine the combat activity of warriors for the coming battle [6].

Thus, S.G. Balchugov considers pedagogical means of forming and developing readiness for a certain activity as a certain complex [7].

\section{Results of the research}

Questions of training a specialist capable of resisting terrorism in all its manifestations have been raised for quite a long time and in almost all countries of the world. Almost every modern state currently has analytical, technical and combat units capable of openly confronting both fanatical terrorists and people who plan, manage and obtain the necessary results after carrying out terrorist acts.

Aware of the danger of spreading the ideas of terrorism, strengthening the international terrorist underground, active sponsorship of terrorist activities by quite «peaceful» countries and corporations, the process of merging terrorist organizations, cross-border and transnational crimes, it is necessary to take an adequate set of measures aimed at eliminating existing and preventing potential terrorist threats at home and abroad.

One of the important areas of prevention of terrorist threats is the professional training (education) of the personnel of law enforcement agencies involved in the fight against terrorism to perform such tasks, including those involving a risk to life.

Petrovanov K.G. in his work gives a political and legal characterization of terrorism as a threat to national security and its main legal institutions [8]. Matus V.G. believes that the need to solve the tasks of strengthening the security of the state, as well as strengthening the fight against crime and terrorism, dictates further strengthening of the personnel and improving the professional training of law enforcement officers [9]. Tarasov M.M. He believes that in the context of the threat from international terrorism, there is an objective need to increase the level of vigilance education in military personnel performing service and combat tasks [10]. Akulin S.V. considers one of the priorities of military educational activities of higher education institutions to be the preservation and multiplication of domestic traditions of training qualified officers, improving the efficiency of the educational process and the quality of professional training of students [11]. According to Korotkov A.A., the state's need for specialists capable of countering terrorism by force is growing more and more. In this regard, the number of special purpose units and rapid response units, which are managed by graduates of military universities with the necessary level of professional training, is growing [12]. V.M. Korovin believes that only a professional, well-trained army with highly effective weapons with a modern level of professional and moral and psychological training of personnel can resist external and internal threats [13]. According to O.A. Kozlov, in modern socio-political conditions that have a multifunctional, emotionogenic nature of service and combat tasks, the National Guard troops place increased requirements on the quality of professional training of graduates of military universities who have professional readiness to organize service and combat activities [14].

When considering and resolving issues related to the formation of the future officer's readiness for anti-terrorist activities, it is necessary to identify the content and structure of this activity itself, i.e., what constitutes the essence of anti-terrorist activities and how it is implemented by the future officer in the military service.

Considering the anti-terrorist activity of the future official, it would be logical to start with its normative legal foundations, since any social phenomenon is a derivative and component of the social system functioning at this stage of society's development. Such a complex phenomenon as terrorism and its nature could not but be reflected in social practice. One of such responses from the society is the regulatory legal regulation of anti- 
terrorist activities. The normative legal basis of anti-terrorist activities, students in the military educational organization of higher education simply need to know. This necessity is dictated by the fact that when carrying out anti-terrorist activities, it is important to understand the legal regulation of this activity and implement this understanding in your practical work.

The legal basis for countering terrorism in the Russian Federation is the Constitution of the Russian Federation, generally recognized principles and norms of international law, international treaties of the Russian Federation, federal laws, normative legal acts of the President of the Russian Federation, normative legal acts of the Government of the Russian Federation, as well as normative legal acts of other federal state authorities adopted in accordance with them. Performing professional tasks, including combating terrorism or preventing the commission of terrorist acts, the officer implements anti-terrorist activities in practice, which must be considered through the analysis of the definitions of «activity»and» anti-terrorist activity».

As a term, this word began to be used in the 19th century in classical German philosophy. In essence, the extract of this use was the understanding of activity by G.V.F. Hegel - the term is used in the triad «goal-activity-material». An activity is something that embodies the original goal (objective, but ideal) in the material (also objective, but real). Activity is the process of realizing the goal, turning the ideal into the material [15]. Leontiev understands activity as a certain system consisting of components of its implementation in the form of relations and interaction of subjects with the surrounding world and themselves [16]. S L. Rubinstein sees in the concept of activity, first of all, a systemic set of actions (functions), indicating that it (activity) is a set of any actions dictated by the teleological nature of the subject's behavior [17]. Shchedrovitsky considers mental activity and also identifies a systemic organization and a subjective character in it [19].

Terrorist activity is the activity of specially trained people or their groups, who most often fulfil someone else's will to create maximum tension in the situation, in the psychoemotional plan, in order to force them to fulfil certain previously defined or formulated on the fly, depending on the success of the operation, requirements imposed on state authorities or local self-government, which most often entail economic benefits. The goal may also be to take away the power to manage the entire society or a separate part of it, again later, as a rule, to obtain this very economic benefit. Except if the person making these claims is not a carrier of a serious psychological illness.

Anti-terrorist activities have a cognitive layer, which is represented, firstly, by the knowledge about the fight against terrorism transmitted during training in the military institute and the further use of this knowledge, and secondly, it includes a specific set of cognitive actions of the future officer to learn his profession and the activities of terrorist organizations on the territory of our country.

Anti-terrorist activities have a management layer, represented on the one hand by the actions of the officer to manage and direct his unit during the implementation of measures to combat terrorism. On the other hand, it is represented by the management activities of higher-level headquarters to plan counter-terrorism measures and ensure their implementation, on time and with the least losses.

Anti-terrorist activity extends as communication between an officer and his subordinates, as well as between an officer and his superiors, and can also consist in interaction with the local population, representatives of other law enforcement agencies, or even the terrorists themselves (for example, during negotiations).

Anti-terrorist activities have specific motives for their implementation, which can be divided into: external and internal. External motives include the need to fulfil the tasks set 
and the orders given, while internal motives include a value attitude to actions to combat terrorism.

Anti-terrorist activities are characterized by emotional and volitional content, since an officer in the performance of tasks to combat terrorism must have mental stability and the will to fight this fight, must be able to overcome their fear and be ready for a sharp change in the operational situation.

Under what conditions does the anti-terrorist activity of an officer of the National Guard take place? How to classify these conditions and what is the significance of their analysis?

The anti-terrorist activity of an officer of the National Guard troops occurs, first, in the conditions of daily performance of professional tasks, the specific content of these conditions depends on the type of military unit where these tasks are performed. If we are talking about special-purpose units, then the conditions of everyday activity are characterized by a high level of dynamism and constant stress of their solution. If these are military units for the protection of important state facilities, then the first place here is the clarity and consistency of tasks, as well as constant work with personnel. If these are special motorized military units or territorial bodies of the Russian Guard, then it should be noted that anti-terrorist activities take place while protecting public order and ensuring public safety.

Speaking about the conditions for the implementation of anti-terrorist activities, it is necessary to note separately the combat conditions of its implementation, when an officer directly has to solve the tasks of defeating terrorists or suppressing their illegal activities, both personally and as part of a unit. Here it is of great importance to take into account all the existing conditions: weather, material and technical, emotional and psychological, personnel, household, legal, physical, etc.

We can talk about countering the ideology of terrorism in the educational environment of military universities, not as a separate system, but only as an inseparable component of patriotic education and cultural education, all forms of work to prevent crimes against military service and of a general criminal nature, prevention of deviant behavior of military personnel, falsification of history to the detriment of Russia, information work with university cadets and raising the level of security culture of military service.

The necessary level of readiness can be achieved with the help of mechanisms of psychophysiological self-regulation, such as extraversion introversion and vegetative regulation, to ensure resilience, relieve psych emotional stress. The level of physiological readiness can determine the state of physical and mental health as physiologically significant qualities for the performance of tasks.

\section{Conclusions}

Based on the system analysis of anti-terrorist activities, we understand the readiness of a future officer for anti-terrorist activities as a complex personal-subjective education containing physiological, emotional-volitional, activity-practical, existential-semantic, cognitive-intellectual, communicative-mental, managerial-subjective and professionalcreative components.

The main psychological and pedagogical conditions for the formation of the readiness of future officers for anti-terrorist activities are: optimization of the educational process based on the integration of the content of education; development of appropriate pedagogical tools, the use of which contributes to the development of the readiness of future officers for anti-terrorist activities; establishment of a system of exchange of service and combat experience between military personnel directly involved in counter-terrorist activities and cadets of military institutes; mastering the skills of information and psychological warfare by cadets and studying the regulatory legal foundations of the fight 
against terrorism; orientation of training tasks to the implementation of anti-terrorist activities by cadets in the future; increasing the extremity and complexity of training tasks, their implementation in conditions close to counter-terrorism (combat, operational and service) [20].

We see that the modeling of the optimization of the educational process in military educational organizations of higher education of the National Guard troops, in order to develop the readiness of future officers for anti-terrorist activities, is the activity of the management of the military institute, the teaching staff and the commanders of cadet units in the following areas: educational, personnel, organizational, regulatory, technological, educational and material-technical. Together, this activity ensures the maximum integration of the functions of all elements of the system improves the quality of planning of the educational process and optimizes the structural content, ensuring the effective development of the readiness of future officers for anti-terrorist activities

Relevant for further research are the issues of the ability and readiness of officers and soldiers to use weapons and special means when participating in counter-terrorism activities, as well as the issues of forming the legal consciousness necessary to combat terrorism. Modern research areas are the search for ways to improve the skills of officers in order to further develop their readiness for anti-terrorist activities and value-based belief in the need to fight terrorism and extremism.

\section{References}

1. L. Bertalanffy, System Theory - A Critical Review, General Systems, VII, 1-20 (1962)

2. I.V. Blauberg, E.G. Yudin, Formation and essence of the system approach, 270 (1973)

3. V.S. Stepin, Philosophy of science, 384 (2006)

4. K.A. Abulkhanova Slavskaya, Activity and personality psychology, 366 (1990)

5. G.G. Dmitriev, Formation of mental readiness for professional activity in military personnel by means of physical training, Theory and practice of physical culture, $\mathbf{8}$, 27-29 (2019)

6. A.G. Karayani, P.A. Korchemny, V.I. Marchenkov, Psychological preparation of military operations of troops, 180 (2011)

7. P.Yu. Naumov, Complex of pedagogical means of forming the readiness of the future officer for research activities, The world of science, culture, and education, 4(47). 175-182 (2014)

8. K.G. Petrovanov, Terrorism as a threat to the national security of the Russian Federation: political and legal support of counteraction, 22 (2005)

9. V.G. Matus, Methodology of special tactical training of employees of the Ministry of Internal Affairs of Russia for actions in special conditions, 213 (2006)

10. M.M. Tarasov, Individual approach in the education of vigilance among cadets of higher educational institutions of the Ministry of Internal Affairs of Russia, 187 (2008)

11. S.V. Akulin, Formation of professional readiness of students in higher education institutions of law enforcement agencies for operational and combat activities, 191 (2014)

12. I.A. Korotkikh, Methodology of technical and tactical adaptation of boxers and wrestlers to applied hand-to-hand combat, 173 (2004) 
13. V.M. Korovin, The system of professional formation of officials in military universities, 188 (2002)

14. O.A. Kozlov, Improving the professional training of cadets of the National Guard troops of the Russian Federation with the help of modern information technologies, 238 (2017)

15. A.V. Borovskikh, Deyatelnostnye principy v pedagogike i pedagogicheskaya logika, $79(2010)$

16. A.N. Leontiev, Activity. Consciousness. Personality, 304 (1977)

17. S.L. Rubinstein, Fundamentals of general psychology, Pedagogika, 2, 321 (1989)

18. I.S. Kon, In search of himself. Personality and its self-consciousness, 336 (1984)

19. G.P. Shchedrovitsky, Sign and activity, 463 (2005)

20. V.V. Kosukhin, Questions of formation of readiness of future officers of the National Guard troops of the Russian Federation for anti-terrorist activities, AMI Publishing House, 88-91 (2019) 